\title{
THE ROLE OF MYOFIBROBLASTS IN GRANULOMATOUS LYMPHADENITIS IN PIGS NATURALLY INFECTED WITH M. AVIUM SUBSP. HOMINISSUIS
}

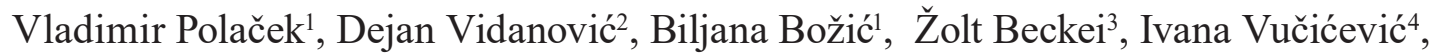 \\ Jasna Prodanov-Radulović1 ${ }^{\text {, Sanja Aleksić-Kovacević }}{ }^{4}$

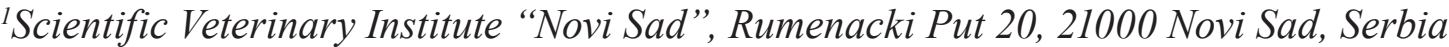 \\ ${ }^{2}$ Veterinary Specialized Institute "Kraljevo", Zicka 34, 36000 Kraljevo, Serbia \\ ${ }^{3}$ Department of Animal Husbandry, Faculty of Veterinary Medicine, \\ Belgrade University, Bulevar Oslobodenja 18, 11000 Belgrade, Serbia \\ ${ }^{4}$ Department of Pathology, Faculty of Veterinary Medicine, Belgrade University, \\ Bulevar Oslobodenja 18, 11000 Belgrade, Serbia
}

Received 13 October 2016; Received in revised form 17 November 2017; Accepted 23 November 2017

\begin{abstract}
The most important morphological characteristic of infections caused by M. avium subsp. hominissuis (MAH) is granuloma formation. The growth of mycobacteria is in accordance with anti-bacterial effector mechanisms of the host within granuloma. The most important cytokines for ,orchestrating“the host defense are interferon $\gamma$ (INF- $\gamma$ ), tumor necrosis factor $\alpha(\mathrm{TNF}-\alpha)$ and transforming growth factor $\beta 1$ (TGF- $\beta 1)$. Myofibroblasts that make up a peripheral layer of granuloma largely express receptors for TGF- $\beta 1$. This cytokine is believed to affect the induction of myofibroblast proliferation. The aim of this paper is to point out the importance of myofibroblasts in the formation and sustainability of granuloma during natural infection of pigs with M. avium subsp. hominissuis. Examinations have been performed on the samples of Lnn. jejunales, Lnn. ileocolici and Lnn. colici of 100 pigs with a positive tuberculin skin test. The molecular method confirmed the presence of a genome M. avium subsp. hominissuis. The microscopic examination of lymph node samples stained by the routine hematoxyilin-eosin (HE) method, showed the presence of granulomatous lymphadenitis. The method of double immunohistochemical staining revealed that myofibroblasts which express TGF- $\beta 1$ receptor type I (TGF- $\beta 1 R I)$ and $\alpha$ smooth muscle actin ( $\alpha$ SMA) have an important role in the morphogenesis of granulomatous lymphadenitis in pigs infected with MAH.
\end{abstract}

Key words: Mycobacterium avium subsp. hominissuis, granuloma, myofibroblast, TGF- $\beta 1$, TGF- $\beta 1$ RI

\section{INTRODUCTION}

Mycobacterium avium, belonging to the Mycobacterium avium complex (MAC), is divided into the subspecies avium, paratuberculosis and silvaticum (1). More recently, M. avium subsp. avium has been further divided into $M$. avium

Corresponding author: Dr. Vladimir Polaček, $\mathrm{PhD}$

E-mail address: vlade@niv.ns.ac.rs

Present address: Scientific Veterinary Institute "Novi Sad", Rumenacki Put 20, 21000 Novi Sad, Serbia

Phone: 381214895 310; Fax: +38121518 544

Copyright: (C) 2017 Polaček V. This is an open-access article published under the terms of the Creative Commons Attribution License which permits unrestricted use, distribution, and reproduction in any medium, provided the original author and source are credited.

Competing Interests: The authors have declared that no competing

interests exist.

Available Online First: 9 December 2017

Published on: 15 March 2018

https://doi.org/10.1515/macvetrev-2017-0030 subsp. avium and M. avium subsp. hominissuis (2). M. avium subsp. hominissuis (MAH) is a ubiquitous microorganism which lives both in water and soil and causes mycobacteriosis of pigs and immunocompromised human population $(3,4$, $5,6)$. The hallmark of MAH infections in pigs are granulomatous lesions localized on gastrointestinal and mandibular lymph nodes (7), but generalized disease is less common and can affect liver, spleen or kidneys. Nevertheless, the morphological changes are not always visible during meat inspection in slaughterhouses (8-12).

Granuloma is a unique form of tissue reaction on presence of agents which are able to provoke a chronic inflammation (10), but development and sustainability of granulomas are controlled by interferon $\gamma$ (INF- $\gamma$ ), tumor necrosis factor $\alpha$ 
$(\mathrm{TNF}-\alpha)$ and transforming growth factor $\beta 1$ (TGF- $\beta 1)(10,11)$. Although cytokine mediated immunosuppressive effect is well known in different infection diseases of pigs, TGF- $\beta 1$ represents an important molecule with distinctive imunomodulating features $(12,13)$. A connection between transforming growth factor - (TGF- $\beta 1$ ) and TH-17 cells has been also investigated and confirmed (14). The cells demarcating granulomas expressing alpha-smooth muscle actin and vimentin, suggest that these cells are myofibroblasts. It is believed that TGF- $\beta$ could affect the induction of myofibroblast proliferation. The aim of this study is to point out the importance of myofibroblasts in the formation and sustainability of granulomas during natural infection of pigs with M. avium subsp. hominissuis.

\section{MATERIAL AND METHODS}

Examinations have been performed on the samples of gastrointestinal lymph nodes (Lnn. jejunales, Lnn. ileocolici and Lnn. colici) of 100 pigs (Norwegian Landrace breed), 5-10 months old and all positive on intradermal comparative tests for bovine and avian tuberculin (Bovitubal and Avitubal, Bioveta, Czech Republic). The pigs imported in Serbia originating from Lithuania were kept in quarantine. Immediately after the euthanasia using T-61 (Merck animal health Intervet, Holland) in accordance with Serbian national animal welfare regulation, autopsy and sampling of gastrointestinal lymph nodes were performed. The tissue samples for microscopic and molecular examinations were fixed 48 hours in a $10 \%$ buffered formalin. After standard tissue processing and paraffin embedding, 4-5 $\mu \mathrm{m}$ thick sections were stained with hematoxylin-eosin (HE) and selected for immunohistochemistry. Formalin fixed and paraffin embedded tissue sections (FFPE) of gastrointestinal lymph nodes of 10 healthy pigs were used as negative control.

Molecular examination on lymph nodes has been performed according to the Norwegian Veterinary Institute protocol described in a previos study (15).

Real-time PCR from FFPE lymph nodes from pigs imported to Serbia

Briefly, one hundred and fifteen FFPE lymph nodes from 100 pigs were sent to the Norwegian Veterinary Institute, and real-time PCRs for detection of DNA sequences of $M$. avium and MTC were performed. For extraction of DNA,
Nucleon HT (Tepnel Life Sciences, Manchester, UK) was applied, following the protocol provided by the manufacturer. From mycobacterial isolates and non-fixed tissue samples, DNA was extracted by Nuclisens ${ }^{\circledR}$ easyMag ${ }^{\circledR}$ (BioMerieux, Inc., Durham, NC, USA) following the manufacturer's instructions. Three singleplex real-time PCRs were developed, for IS1245 and IS6110 specific for M. avium and MTC respectively, and for the porcine P-globin gene. Amplification of the latter sequence was used as a positive control for successful DNA extraction from the samples. Primers and 6FAM labelled TaqMan MGB probes were designed using the program Primer 3.0 (http://frodo.wi.mit.edu/ primer3/) (Table 1). Real-time PCR was performed using Stratagene Mx3005P (Stratagene, La Jolla, CA, USA). Reaction mixtures had a total volume of $20 \mid \pi$, consisting of $2 \mid \pi$ template DNA at a concentration of 10-15 ng/Л, $10 \mid Л$ PerfeC Тa ${ }^{\circledR}$ qPCR FastMix ${ }^{\circledR}$ (Quanta Biosciences, Gaithersburg, $\mathrm{MD}$, USA), and primers and probes at a final concentration of 400 and $150 \mathrm{nM}$, respectively.

DNA extracted from FFPE lymph nodes from animals clinically infected with $M$. avium subsp. hominissuis or M. bovis, verified by culture prior to fixation, were used for optimization of PCR conditions. DNA extracted from M. avium ATCC 25291, M. bovis BCG (Danish strain 1331) and from a porcine spleen, were used as positive controls for IS1245, IS6110 and P-globin. Ultrapure Milli-Q water was used for adjustment of volume and concentrations and as a template substitute in negative controls.

The real-time PCR reactions were initiated with denaturation at $95^{\circ} \mathrm{C}$ for $10 \mathrm{~min}$, followed by 45 runs of the following thermal cycle: $95{ }^{\circ} \mathrm{C}$ for $3 \mathrm{sec}$ and $60^{\circ} \mathrm{C}$ for $30 \mathrm{sec}$. All samples and controls were run as single measurements. The results were analyzed using Stratagene MxPro 4.10 software (Stratagene), applying the automatic calculation of the threshold fluorescence. Ct values above 40 were regarded as negative as recommended by the manufacturer (Stratagene).

\section{Microscopic examination}

According to microscopical features, granulomas were classified into three groups: 1. Granulomas without necrosis, 2. Granulomas with an initial necrosis and 3. Granulomas with distinctive necrosis and calcification.

\section{Immunohistochemical examinations}

Immunohistochemical examinations were carried out on formalin fixed and paraffin 
Table 1. Primary antibodies used in IHC (LSAB2) procedure

\begin{tabular}{cccc}
\hline Primary antibody & Dilution & Incubation & Antigen demasking \\
\hline $\begin{array}{c}\text { TGF- } \beta 1 \\
\text { (Santa Cruz Biotechnology sc-146) }\end{array}$ & $1: 150$ & $18 \mathrm{~h} / 4^{\circ} \mathrm{C}$ & citrate buffer $\mathrm{pH}=6 / 560 \mathrm{~W} / 21 \mathrm{minute}$ \\
\hline $\begin{array}{c}\text { TGF- } \beta 1 \mathrm{RI} \\
\text { (Santa Cruz Biotechnology sc-402) }\end{array}$ & $1: 150$ & $18 \mathrm{~h} / 4^{\circ} \mathrm{C}$ & citrate buffer $\mathrm{pH}=6 / 560 \mathrm{~W} / 21$ minute \\
\hline
\end{tabular}

Table 2. Primary antibodies used in the method of double IHC staining (DAKO Envision GI2 Doublestain)

\begin{tabular}{|c|c|c|c|}
\hline Primary antibody & Dilution & Incubation & Antigen demasking \\
\hline $\begin{array}{c}\alpha-S M A \\
(\text { DAKO M 0851) }\end{array}$ & $1: 50$ & 10 minutes $/ 18^{\circ} \mathrm{C}$ & citrate buffer $\mathrm{pH}=6 / 560 \mathrm{~W} / 21$ minute \\
\hline $\begin{array}{c}\text { TGF- } \beta 1 \text { RI } \\
\text { (Santa Cruz Biotechnology sc-402) }\end{array}$ & $1: 100$ & 10 minutes $/ 18^{\circ} \mathrm{C}$ & citrate buffer $\mathrm{pH}=6 / 560 \mathrm{~W} / 21$ minute \\
\hline
\end{tabular}

embedded tissue sections. Streptavidin-biotin imunohistochemical method (DAKO, LSAB2) and the double IHC staining method for simultaneous detecting of two antigens ( $\alpha$ SMA/ TGF- $\beta 1 \mathrm{RI}$ ) in the same tissue section (DAKO Envision GI2 Doublestain) were used. The description of primary antibodies dilution, incubation and antigen retrieval are given in Table 1 and Table 2. Briefly, in LSAB2 endogenous peroxidase was blocked in $3 \% \mathrm{H}_{2} \mathrm{O}_{2}$ at $18^{\circ} \mathrm{C}, 15$ minutes followed by antigen retrieval in citrate buffer $\mathrm{pH}=6,560 \mathrm{~W}$, $21 \mathrm{~min}$. For vizualization of positive reaction, 3' diaminobenzidine tetrachloride $(D A B+)$, was used as a chromogene. Counterstaining was performed in Mayer hematoxylin and the slides were mounted in a water mounting medium, Glycergel (DAKO, C 563). The tissue sections without primary antibodies were used as negative control, while the tissue sections already positive to examined antigens served as positive control. For simultaneous visualization of two different antigens on the same tissue section "DAKO Envision GI2 Doublestain“ system (K5361) was used. Microsscopic examinations were performed using microscope Olympus BX51.

\section{RESULTS}

Real-time PCR from FFPE lymph nodes from pigs imported to Serbia

The Norwegian Veterinary Institute received 115 FFPE lymph nodes from the Serbian pigs in order to confirm the presence of MAC. Twentythree samples were excluded from real-time PCR analysis. Only one sample was included from each pig. Additionally, samples with uncertain sample ID or poor DNA quality measured by negative result on real-time PCR for the porcine P-globin gene were excluded. Of the 92 remaining samples analysed for the presence of IS1245 by real-time PCR, 51 $(55.4 \%)$ were regarded positive. Ten $(10.9 \%)$ of the 92 samples analysed by IS6110 real-time PCR were considered positive, all but three were however simultaneously positive in IS1245 PCR. The PCR products of the samples positive for IS6110 were additionally sequenced and compared to published sequences by NCBI BLAST (http://blast.ncbi.nlm. nih.gov/Blast.cgi) to confirm their identity. Of the pigs with neither microscopic nor macroscopic lesions, only one of eight samples examined was positive for IS1245 by PCR, and none were positive for IS6110. In samples from 38 of the tuberculin reactors no IS element could be detected.

The results of microscopic immunohistochemical investigation

The microscopic examination of all PCR positive lymph node samples for IS1245 (51) stained by the routine Hematoxylin-eosin (HE) method showed the presence of granulomatous lymphadenitis.

Positive cytoplasmic reaction for transforming growth factor TGF- $\beta 1$ was detected predominantly on macrophages in granulomas, as well as on some lymphocytes. Expression of TGF- $\beta 1$ was of lower 




Figure 1. Microscopic and immunohistochemical finding in a gastrointestinal lymph node of pigs infected with Mycobacterium avium subsp hominissuis. Macrophages and lymphocytes around the area of caseous necrosis in a granuloma, HE (A); Numerous giant cells in a granuloma, HE (B); Expression of TGF- $\beta 1 R I, ~ L S A B 2 ~(C)$; Expression of TGF- $\beta 1$, LSAB2 (D)

intensity in granulomas with prominent fibrosis, necrosis and calcification. The high expression of TGF- $\beta 1$ was present in macrophages in the early

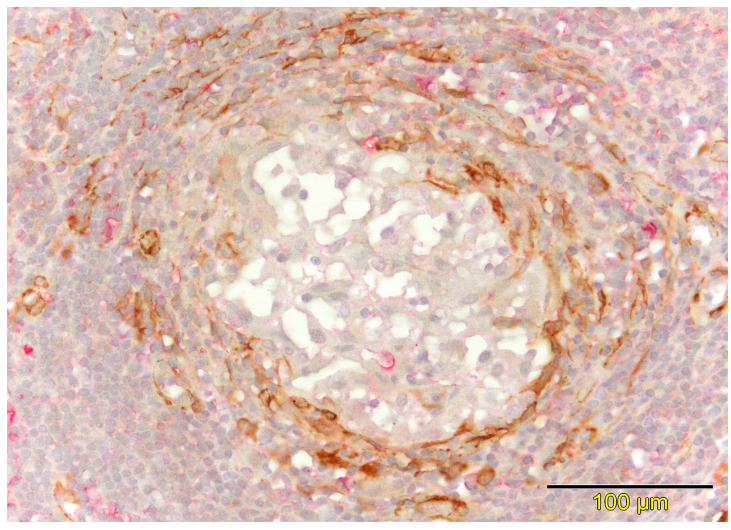

Figure 2. Immunochistochemical finding in a gastrointestinal lymph node of pigs infected with Mycobacterium avium subsp hominissuis. Expression of $\alpha$ SMA/ TGF- $\beta 1 R I$, double immunohisochemical staining, DAB/PR. ( $\alpha$ SMA - brown chromogen, TGF$\beta 1 R I$ - pink chromogen) stages of granuloma development, while the very necrotic center of a granuloma was always negative to TGF- $\beta 1$. (Fig. $1 \mathrm{C}$ ).

Receptor TGF- $\beta 1$ RI for TGF- $\beta 1$ molecule was exclusively expressed on myofibroblasts. Besides this signalling molecule, in the tissue samples stained by double immunohistochemical staining many of myofibroblasts simultaneously expressed smooth muscle actin $\alpha \mathrm{SMA}$ and TGF$\beta 1 R I$. Reaction to $\alpha \mathrm{SMA}$ was homogenous and cytoplasmic. The $\alpha \mathrm{SMA}$ expression was commonly detected in the cytoplasm of myofibroblasts at granuloma peripheries (Fig. 2).

\section{DISCUSSION}

Granulomatous inflammation is a basic morphological characteristic of immune response to infection caused by mycobacteria. Granulomas are formed as immune response to infection of mycobacterium and they represent lesions where epithelioid cells, giant cells, fibroblasts and lymphocytes of various immunophenotypes are 
located usually around a necrotic and/or calcified center (16, 17). However, all immunophenotypic characteristics of effector cells in granulomas important for pathogenesis of swine mycobacteriosis are not well described. The ratio of myofibroblasts, epithelioid cells and occurrence of necrosis is controlled by various factors, but attention is paid mainly to TGF- $\beta 1$ (18). It is believed that cytokines and growth factors which cause necrosis also lead to myofibroblast stimulation (TGF- $\beta$ ) supporting that that myofibroblasts have a significant role in formation of granulomas caused by mycobacterium (19). When activated, myofibroblasts express adhesive molecules for lymphocytes, mast cells and neutrophil granulocytes. They also participate in formation of tissue granulomas and play a significant role in inflammatory reactions, having in mind that they produce important inflammatory mediators (18). It is assumed that TGF- $\beta 1$ induces proliferation of myofibroblasts in granulomas, which changes interpretation of its role considering that this factor has been also ascribed an inhibitory role in activation of macrophages in granulomatous lesions in tuberculosis. Some authors showed that myofibroblasts have a particularly important role in formation of granulomas caused by MAC in pigs (18, 20). They also emphasize the connection between the number of myofibroblasts and expression of TGF- $\beta 1$ (21). Our previous results indicate that TGF- $\beta 1$ induces proliferation of myofibroblasts. However current investigation reveals the important role of expression of TGF- $\beta 1$ RI receptors in the development of granulomatous lymphadenitis in pigs infected by M. avium subsp. hominissuis.

Similary, in humans the number of myofibroblasts increases with the maturity of tuberculous granuloma, while these cells were found in low numbers in an early granulomatous lesion formed predominantly from epithelioid cells (18). Finally, immunoreactivity of TGF- $\beta 1$ decreases with the progression fibrosis in granuloma (18). TGF- $\beta 1$ is also considered responsible for reduced sensitivity to INF- $\gamma$ in human infections caused by MAC and experimental infection with $M$. bovis in cattle (11, $18,21)$. Immunohistochemistry of lung granuloma reveals the location of TGF- $\beta$ primarily in giant cells of Langerhans type, and to a lesser extent in other macrophages (18). Using the immunohistochemical method, our study showed that the principal source of TGF- $\beta 1$ molecules in granulomas of pigs infected with MAC are macrophages. Additionally, the cells demarcating granulomas expressing alpha-smooth muscle actin and vimentin, suggest that these cells are myofibroblasts.
Similarity between immunopathogenesis of infections by MAC in pigs and humans is pointed out by Hybiya et al. (17) showing the same pattern of MAC granuloma development in pigs and immunocompromised humans both infected with M. avium.

\section{CONCLUSION}

Our results underline the role of myofibroblasts in morphogenesis of granulomatous lymphadenitis of pigs naturally infected with $M$. avium subsp. hominissuis. The double immunohistochemical staining showed that myofibroblasts which express TGF- $\beta 1 R I$ and $\alpha$ SMA play a key role in the morphogenesis of granulomatous lymphadenitis in pigs infected with Mycobacterium avium subsp. hominissuis. Infections of pigs with M. avium subsp. hominisuis have characteristics similar to infections with MAC in humans and therefore could be used also for studying pathogenesis of micobacterial infections in humans.

\section{CONFLICT OF INTEREST}

The authors declared that they have no potential conflict of interest with respect to the authorship and/or publication of this article.

\section{ACKNOWLEDGEMENT}

We thank Tone Bjordal Johansen and Angelika Agdeinstain from the Norwegian Veterinary Institute for their help with real time PCR diagnostics and Danka Vukasinovic for helping translate the article. The research was partly conducted within the project of the Ministry of Education and Science of the Republic of Serbia, under the registration number TR31071, TR31084 and III46002.

\section{REFERENCES}

1. Inderlied, C.B., Kemper, C.A., Bermudez, L.E. (1993). The Mycobacterium avium complex. Clin Microbiol Rev. 6 (3): 266-310. https://doi.org/10.1128/CMR.6.3.266 PMid:8358707 PMCid:PMC358286

2. Johansen, T., Agdestein, A., Olsen, I., Nilsen, S., Holstad, G., Djønne, B., et al. (2009). Biofilm formation by Mycobacterium avium isolates originating from humans, swine and birds. BMC Microbiol. 9(1): 159.

https://doi.org/10.1186/1471-2180-9-159

PMid:19660141 PMCid:PMC2741467 
3. Agdestein, A., Olsen, I., Jørgensen, A., Djønne, B., Johansen, T.B. (2014). Novel insights into transmission routes of Mycobacterium avium in pigs and possible implications for human health. Vet Res. 45, 46.

https://doi.org/10.1186/1297-9716-45-46

PMid:24742183 PMCid:PMC4021465

4. Bezos, J., Álvarez-Carrión, B., Rodríguez-Bertos, A., Fernández-Manzano, Á., de Juan, L., Huguet, C., et al. (2016). Evidence of disseminated infection by Mycobacterium avium subspecies hominissuis in a pet ferret (Mustela putorius furo). Research in Veterinary Science 109, 52-55.

https://doi.org/10.1016/j.rvsc.2016.09.013

PMid:27892873

5. Matlova, L., Dvorska, L., Ayele, W.Y., Bartos, M., Amemori, T., Pavlik, I. (2005). Distribution of Mycobacterium avium complex isolates in tissue samples of pigs fed peat naturally contaminated with mycobacteria as a supplement. J Clin Microbiol. 43(3): 1261-1268.

https://doi.org/10.1128/JCM.43.3.1261-1268.2005 PMid:15750094 PMCid:PMC1081227

6. Biet, F., Boschiroli, M.L. (2014). Non-tuberculous mycobacterial infections of veterinary relevance. Res Vet Sci. 97, S69-77.

https://doi.org/10.1016/j.rvsc.2014.08.007 PMid:25256964

7. Polaček, V., Aleksić-Kovačević, S. (2016). Mycobacteriosis in pigs - an underrated threat. Acta Vet Beograd. 66(4): 429-443. https://doi.org/10.1515/acve-2016-0037

8. Pate, M., Zdovc, I., Pirs, T., Krt, B., Ocepek, M. (2004). Isolation and characterisation of Mycobacterium avium and Rhodococcus equi from granulomatous lesions of swine lymph nodes in Slovenia. Acta Vet Hung. 52(2): 143-150. https://doi.org/10.1556/AVet.52.2004.2.2 PMid:15168745

9. Agdestein, A., Johansen, T.B., Kolbjørnsen, Ø., Jørgensen, A., Djønne, B., Olsen, I. (2012). A comparative study of Mycobacterium avium subsp. avium and Mycobacterium avium subsp. hominissuis in experimentally infected pigs. BMC Vet Res. 8(1): 11.

https://doi.org/10.1186/1746-6148-8-11 PMid:22284630 PMCid:PMC3296603

10. Saunders, B.M., Britton, W.J. (2007). Life and death in the granuloma: immunopathology of tuberculosis. Immunol Cell Biol. 85(2): 103-111. https://doi.org/10.1038/sj.icb.7100027 PMid:17213830
11. Wangoo, A., Johnson, L., Gough, J., Ackbar, R., Inglut, S., Hicks, D., et al. (2005). Advanced granulomatous lesions in Mycobacterium bovisinfected cattle are associated with increased expression of type I procollagen, (WC1+) T cells and CD 68+ cells. J Comp Pathol. 133(4): 223-234. https://doi.org/10.1016/j.jcpa.2005.05.001 PMid:16154140

12. Miković, R., Knežević, A., Milić, N., Krnjaić, D., Radojičić, M., Veljović, L., et al. (2016). Molecular detection of pseudorabies virus (PrV), porcine parvovirus (PPV) and porcine circovirus 2 (PCV2) in swine in Republic of Montenegro. Acta Vet Beograd. 66(3): 347-358.

https://doi.org/10.1515/acve-2016-0030

13. Lukač, B., Knežević, A., Milić, N., Krnjaić, D., Veljović, L., Milićević, V., et al. (2016). Molecular detection of PCV2 and PPV in pigs in Republic of Srpska, Bosnia and Herzegovina. Acta Vet Beograd. 66(1): 51-60.

https://doi.org/10.1515/acve-2016-0004

14. Veldhoen, M., Hocking, R.J., Flavell, R.A., Stockinger, B. (2006). Signals mediated by transforming growth factor- $\beta$ initiate autoimmune encephalomyelitis, but chronic inflammation is needed to sustain disease. Nat Immunol. 7(11): 1151-1156.

https://doi.org/10.1038/ni1391

PMid:16998492

15. Agdestein, A., Johansen, T.B., Polaček, V., Lium, B., Holstad, G., Vidanović, D., et al. (2011). Investigation of an outbreak of mycobacteriosis in pigs. BMC Vet Res. 7, 63.

https://doi.org/10.1186/1746-6148-7-63

PMid:22014189 PMCid:PMC3215643

16. Birkness, K., Guarner, J., Sable, S.B., Tripp, R., Kellar, K.L., Bartlett, J., et al. (2007). An in vitro model of the leukocyte interactions associated with granuloma formation in Mycobacterium tuberculosis infection. Immunol Cell Biol. 85(2): 160-168.

https://doi.org/10.1038/sj.icb.7100019

PMid:17199112

17. Hibiya, K., Kasumi, Y., Sugawara, I., Fujita, J. (2008). Histopathological classification of systemic Mycobacterium avium complex infections in slaughtered domestic pigs. Comp Immunol Microbiol Infect Dis. 31(4): 347-366. https://doi.org/10.1016/j.cimid.2007.05.001 PMid:17629560 
18. Fujita, J., Ohtsuki, Y., Suemitsu, I., Yamadori, I., Shigeto, E., Shiode, M, et al. (2002). Immunohistochemical distribution of epithelioid cell, myofibroblast, and transforming growth factorbetal in the granuloma caused by Mycobacterium avium intracellulare complex pulmonary infection. Microbiol Immunol. 46(2): 67-74. https://doi.org/10.1111/j.1348-0421.2002.tb02660.x PMid:11939580

19. Kaarteenaho-Wiik, R., Sademies, O., Pääkkö, P., Risteli, J., Soini, Y. (2007). Extracellular matrix proteins and myofibroblasts in granulomas of sarcoidosis, atypical mycobacteriosis, and tuberculosis of the lung. Hum Pathol. 38(1): 147-153. https://doi.org/10.1016/j.humpath.2006.07.001

PMid:16996565
20. Polaček, V., Vidanović, D., Vasković, N., Knežević, M., Gledić, D., Aleksić-Kovačević, S., et al. (2010). Distribution of myofibroblasts, transforming growth factor- $\beta 1$ and transforming growth factor- $\beta 1$ receptor-I in granulomas caused by Mycobacterium avium complex in pigs. J Comp Pathol. 143(4): 326. https://doi.org/10.1016/j.jcpa.2010.09.051

21. Cvetkovikj, I., Mrenoshki, S., Krstevski, K., Djadjovski, I., Angjelovski, B., Popova, Z., et al. (2017). Bovine tuberculosis in the republic of Macedonia: Postmortem, microbiological and molecular study in slaughtered reactor cattle. Mac Vet Rev. 40(1): 43-52. https://doi.org/10.1515/macvetrev-2016-0097

Please cite this article as: Polaček V., Vidanović D., Božić B., Beckei Ž., Vučićević I., Prodanov-Radulović J., Aleksić- Kovacević S. The role of myofibroblasts in granulomatous lymphadenitis in pigs naturally infected with M. avium subsp. Hominissuis. Mac Vet Rev 2018; 41 (1): 47-53. https://doi.org/10.1515/macvetrev-2017-0030 